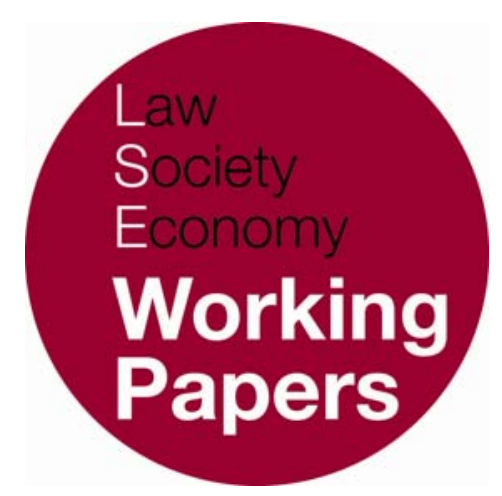

From Moll Flanders to Tess of the

D’Urbervilles: Women, Autonomy and

Criminal Responsibility in Eighteenth and

Nineteenth Century England

\author{
Nicola Lacey \\ LSE Law, Society and Economy Working Papers 5/2007 \\ London School of Economics and Political Science \\ Law Department
}

This paper can be downloaded without charge from LSE Law, Society and Economy

Working Papers at: www.lse.ac.uk/collections/law/wps/wps.htm

and the Social Science Research Network electronic library at: http://ssrn.comabstract $=1012282$

(C) Nicola Lacey. Users may download and/or print one copy to facilitate their private study or for non-commercial research. Users may not engage in further distribution of this material or use it for any profit-making activities or any other form of commercial gain. 


\title{
From Moll Flanders to Tess of the D’Urbervilles: Women, Autonomy and Criminal Responsibility in Eighteenth and Nineteenth Century England
}

\author{
Nicola Lacey*
}

\begin{abstract}
In the early $18^{\text {th }}$ Century, Daniel Defoe found it natural to write a novel whose heroine was a sexually adventurous, socially marginal property offender. Only half a century later, this would have been next to unthinkable. In this paper, the disappearance of Moll Flanders, and her supercession in the annals of literary female offenders by heroines like Tess of the d'Urbervilles, serves as a metaphor for fundamental changes in ideas of selfhood, gender and social order in $18^{\text {th }}$ and $19^{\text {th }}$ Century England. Drawing on law, literature, philosophy and social history, I argue that these broad changes underpinned a radical shift in mechanisms of responsibility-attribution, with decisive implications for the criminalisation of women. I focus in particular on the question of how the treatment and understanding of female criminality was changing during the era which saw the construction of the main building blocks of the modern criminal process, and of how these understandings related in turn to broader ideas about gender, social order and individual agency.
\end{abstract}

\section{INTRODUCTION}

In 1722, Daniel Defoe sent out into the world one of the most remarkable female figures in English literature: Moll Flanders. ${ }^{1}$ Bold, beautiful and brilliantly resourceful, Moll was in many ways ideally qualified for her position as the heroine of what is often regarded as the first true novel in English. She did, however, exhibit one characteristic which we might have expected to exclude her from that position. For most of the novel, her primary occupation consists in a series of distinctly unromantic property offences, including a variety of forms of shoplifting, swindling and even stealing from small children. Born in Newgate gaol of a mother who has escaped execution by 'pleading her belly', and who is transported to Virginia after Moll's birth, Moll escapes her origins at the heart of

\footnotetext{
* Professor of Criminal Law and Legal Theory at the LSE. This paper sketches some of the ideas which will be developed in the Clarendon Lectures, to be delivered in the Law Faculty at Oxford University on October $31^{\text {st }}$ and November 1st 2007, and to be published by OUP in 2008. For further details of the lectures and publication, please email either Nicola Lacey(n.lacey@lse.ac.uk) or Ros Wallington (r.wallington@oup.com).

${ }^{1}$ Daniel Defoe, Moll Flanders (Penguin Books, 1989).
} 
the criminal underworld in her early life, only to be forced to return to it after the death of her first husband, when want of wealth and birth prevent her from finding a secure position in respectable society. Using her beauty, ingenuity and cunning, Moll escapes poverty and makes her way through late 17th Century England by means of property crime, before ultimately being caught, convicted and transported to Virginia along with one of her five husbands, himself a convicted highwayman. Adding colour to this pattern of thieving and deception, Moll enjoys an active and varied love life, encompassing both incest and bigamy, with plentiful instances of the more quotidian diversions of fornication and adultery thrown in for good measure.

Ostensibly, Moll Flanders is a tale of sin and repentance. While awaiting her punishment in Newgate, Moll experiences a mental collapse and renounces her criminal habits. She is ultimately rewarded with riches and success gained by good fortune and legitimate use of her prodigious talents. It is nonetheless hard for the modern reader entirely to believe in her reformation. For the new, respectable, wealthy Moll is the very same Moll as the thieving and deceiving Moll, and for a morality tale, the painful moments of her regret and punishment are extraordinarily brief. As Juliet Mitchell aptly put it, Moll is 'a small-time capitalist in the making, she is the pilgrim progressing to what, as a sharp-witted child and clear-headed woman, she rightly takes to be the capitalist definition of a gentlewoman - the wife of a prosperous businessman or a self-made woman in her own right...it is not the righteous ending that prevents Moll from being a pornographic tale of wickedness but rather the fact that Moll is good even while a thief and a prostitute and just as bad or just as good even while she is a wife and investor.'2 It is as if - in stark contrast to John Bunyan's Christian in The Pilgrim's Progress (1678) (another candidate for the place of first English novel), Defoe's genius in creating Moll's vividly autonomous personality outstrips his moral purpose. If Defoe's message was that redemption is always available to the true penitent, it must also be said that he conveys very forcefully that wit, courage and enterprise are valuable attributes for a woman; and it is these which ultimately make of Moll a successful gentlewoman as much as a successful thief.

Before turning to Moll's literary cousin, Tess of the d'Urbervilles, it is worth pausing to note the striking contrast between Defoe's image of female criminality and that to be found in criminology. Women's relatively low representation among offenders, and the strong cultural association of notions of criminality and deviance with characteristics culturally marked as masculine, consigned female offenders to the outer margins of the discipline until the pioneering work of feminist writers like Carol Smart in the 1970s. ${ }^{3}$ As feminist criminologists noted,

2 J. Mitchell, 'Moll Flanders, The Rise of Capitalist Woman' in her Women: The Longest Revolution (London: Virago, 1984) 203-4; reprinted from her introduction to the Penguin edition of Moll Flanders (Harmondsworth: Penguin, 1978).

${ }^{3}$ Carol Smart, Women, Crime and Criminology (London: Sage, 1976); see also Ngaire Naffine, Female Crime: the construction of women in criminology (Sydney: Allen and Unwin, 1987); Frances Heidensohn, Women and 
women offenders tend to be thought of as weak-minded or mad rather than bad: or, when engaged in behaviour sufficiently subversive of conventional norms of femininity, as 'doubly deviant'. Female offenders also tend to be seen as victims: victims of their hormones, of their circumstances and, sometimes, of men. The idea that choices, agency or reason are important factors in their offending behaviour surfaces implicitly in theories rooted in distinctively gendered opportunity structures, but is rarely emphasised (and here feminist criminologists have sometimes unwittingly echoed the assumptions of the criminological traditions which they criticise). ${ }^{4}$ The female gendering of particular defences such as mental incapacity defences like diminished responsibility (as opposed to 'masculine' defences like provocation and self-defence) has also been widely noted. ${ }^{5}$ The criminological image of the female offender has often approached the ultimate stereotype of conventional femininity: passive rather than active; driven by emotion rather than reason; moved by impulses located in the body rather than the mind.

Moll Flanders could not stand in greater contrast to this stereotyped image. For Moll is a thoroughly autonomous woman, brimming with agency and enterprise: she has plans and ambitions; she has strategies for pursuing them; she reflects upon, and has an account of, her own behaviour ${ }^{6}$ - explicitly linking the need to steal with her insecure position in society and lack of legitimate means of support, and on occasion inveighing against the sexual double standard. Though hardly burdened with an overactive superego, she has a conscience, and feels shame and guilt about both her unwittingly incestuous marriage and her momentary temptation to kill. She also suffers feelings and perplexities which we would be inclined to associate with the experience of a much later version of capitalism: even when she has become wealthy through crime, she finds that she is unable to give up the thrill of stealing and, in a manner somewhere between conspicuous consumption and addiction to risk, continues until she is caught. Perhaps most significantly, Moll is a strong, active and dominant woman, and her world is peopled by several other women similar to herself (notably her 'mistress', a high class receiver and pawnbroker). The men in this world are, by contrast, often weak, indecisive and passive. Some critics have suggested that Moll is in effect gendered masculine: Virginia Woolf noted that she was a 'person rather than a woman', and one recent biographer has even gone so far as to suggest that she represented Defoe's alter ego - an outlet for some of the more exotic

Crime (New York: New York University Press, 1985); Allison Morris, Women, Crime and Criminal Justice (Oxford: Basil Blackwell, 1987).

${ }^{4}$ As Garthine Walker has argued, the same has often been true of historical accounts: Crime, Gender and Social Order in Early Modern England (Cambridge: CUP, 2003), Chapter 6. Walker's book by contrast gives a central place to women's agency.

${ }^{5}$ For example by Susan Edwards, Women on Trial (Manchester: Manchester University Press, 1984).

${ }^{6}$ In precisely the style of Charles Taylor's self-interpreting human subject: Sources of the Self (Cambridge: CUP, 1989). 
predispositions of her gloriously complicated, bisexual creator. ${ }^{7}$ Whatever the truth of these assertions, the key point for our purposes is that Moll's literary success implies that her early readers received her as entirely plausible. Moll Flanders is, in short, a fully responsible subject, and the very antithesis of the frail, emotional, dominated woman one might have expected to find in a novel of its time.

Let us now jump forward to the late $19^{\text {th }}$ Century, and to a very different female heroine: Tess of the D’Urbervilles, who appeared to sharply divided public reaction in $1891 . .^{8}$ Moll and Tess share certain characteristics: both are beautiful, both are proud of their beauty and have a sense of themselves as special, an aspiration to transcend their difficult origins; both have significant resources of determination; both feel lasting emotional attachments; and both commit offences. But here the resemblance ends. Notwithstanding her relatively respectable origins, Tess's tale is one of a human being destroyed by her circumstances and, ultimately, by her own decisions. Her crime - which, significantly, takes place behind doors which the reader is not allowed to open - is a crime of passion: the murder of the man who, by raping her, set in motion the train of events which leads to her ruin. And her punishment is swift, decisive and annihilating - despite the fact that, unlike Moll, she is certainly not represented as a danger to society. Hardy suggests a number of causes for Tess's ultimate act of revenge, several of which evoke late Victorian images of female criminal pathology: a hereditary capacity for impulsive acts of violence and a dissociation of the will from the body notable among them. ${ }^{9}$ Yet Tess is not - as one might have expected from a late $19^{\text {th }}$ Century novel treating female crime - an image of female weak-mindedness or incapacity. What Hardy most certainly gives us in Tess, however, is an image of female powerlessness and of the futility of female selfassertion or rebellion. Like most female offenders who feature, as heroines or otherwise, in $19^{\text {th }}$ Century novels - they are mainly husband-murders, infanticides and prostitutes - Tess's position as a woman underlines her social powerlessness: notwithstanding her strong sense of personal responsibility, and her creator's evident indictment of the sexual double standard, this late Victorian heroine, unlike Moll, is not able - or, perhaps, not allowed - to shape her own destiny. While Defoe allows Moll to assert her strong sense of self - at one point, cutting off a digression about her husband, she insists, 'this is my story, not his'...10 Tess's self-assertion leads to disaster.

7 See, variously, Mitchell n 2 above; J. Martin, Beyond Belief: The Real Life of Daniel Defoe (Ebbw Vale, Accent Press, 2006); I. Watt, The Rise of the Novel (Berkeley: University of California Press, 1957).

8 1891, New York: Bantam Classic, 2004. Though Tess met with critical acclaim, many of her early readers were scandalized by the book, not least by Hardy's treatment of sex.

${ }^{9} \mathrm{n} 8$ above, 401, 406, 394-5.

${ }^{10}$ n 2 above, 380; cf. Roxana, (1724, Oxford: Oxford World's Classics, 1996) Defoe's other - and equally vivid - female protagonist. Like Moll's, Roxana's is a tale of sin and repentance, but Roxana even goes so far as to meditate on whether her repentance was caused by conscience or by misery: after all, she reflects, she did not repent when still fortunate... Defoe's work has sometimes been marginalized in accounts of the development of the genre, not least because of his concern with 'impolite' spheres of life relegated to the margins of the $18^{\text {th }}$ Century novel from Richardson on. 
In this paper, I want to argue that this change has to do not so much with the disappearance of feminine agency: rather, it is a question of the social consequences of women's exercise of their agency and expression of them selves. The closest $19^{\text {th }}$ Century literary analogy to Moll - Becky Sharp, anti-heroine of Thackeray's Vanity Fair (1847-8) ${ }^{11}$ - is decisively punished for the unscrupulous use to which she puts her intellect and resourcefulness. Devoid of Moll's humane qualities, Becky is not so much a heroine as the device which Thackeray uses to hold up to ridicule the corruption of Regency society. And though he is undoubtedly the creator of Victorian fiction's most spectacularly intelligent female figure, in Becky's friend Amelia, Thackeray also gives voice to the emerging stereotype of female weakness: of her son, he comments that 'He had been brought up by a kind, weak, and tender woman, who had no pride about anything but about him, and whose heart was so pure and whose bearing was so meek and humble that she could not but needs be a true lady. She busied herself in gentle offices and quiet duties; if she never said brilliant things, she never spoke or thought unkind ones; guileless and artless, loving and pure, indeed how could our poor little Amelia be other than a real gentlewoman!'12 By the time of Tess, the idea of a figure such as Moll Flanders - a sassy, cunning, warm and rather successful property offender and manipulator of men - as the unambiguous heroine of a novel would be unthinkable.

I also want to explore what the 19 $19^{\text {th }}$ Century unthinkability of Moll Flanders signifies about both the images of women's autonomy and the reality of women's criminality in the flow of historical development through the 18th and $19^{\text {th }}$ Centuries. What, if anything, can cultural products like novels tell us about changes in social practices and institutions such as those contributing to the criminalisation? There are two particular reasons for regarding this as a potentially fruitful line of inquiry. First, over these two centuries we have, at just the same time as a period of rapid social change and institutional innovation in criminal justice, the rapid development of literary fiction which aspires to 'realism'. Quite apart from the images of criminal justice practice to be found in the novels particularly, of course, the novels of Henry Fielding, who was at once one of the greatest writers and one of the most important criminal justice commentators and reformers of the $18^{\text {th }}$ Century - they are a rich source of insight into prevailing social attitudes and mores. And there is particular reason to think that these were of decisive importance to the conduct of criminal justice in the $18^{\text {th }}$ and early $19^{\text {th }}$ Centuries. This is because the system - if indeed it is aptly characterized as such was still largely administered not by professional criminal justice officials and lawyers but by ordinary citizens in their roles as justices of the peace, parish constables and people bringing prosecutions or testifying about offences.

Those of us interested in this period are fortunate to be able to draw on a rich historiography illuminating the highly discretionary and decentralized nature of

11 1848, rev. ed. 1851, Penguin Classics 2001.

12 ibid 654 
$18^{\text {th }}$ Century criminal justice. ${ }^{13}$ Criminal justice was largely administered at the local level: assize judges travelling the circuits from London carried the personal authority of the monarch, but it was rather the authority of local landowners and, later, clerics, relatively well-to-do merchants and industrialists in their capacity as Justices which shaped the application of a law which, particularly from the mid18th Century on certainly merited its nickname, 'the Bloody Code'. With no organized police force, let alone prosecuting authority, the (inevitably uneven) enforcement of criminal law depended on private initiative - a system which, as Fielding was quick to point out in both his political and writing and his novels, ${ }^{14}$ was wide open to corruption. The attitudes and assumptions of those prosecuting crime, those testifying as witnesses, those acting as filters on grand juries, not to mention petty trial juries and Justices at the Quarter Sessions which heard the vast bulk of criminal cases, were therefore crucial in shaping the operation of the process. And though the $18^{\text {th }}$ Century saw - to use John Langbein's term ${ }^{15}-$ the gradual 'lawyerisation' of the trial, this development applied primarily to assize cases. (Though numbers are a crude measure of their relative importance, it is perhaps worth noting here that it has been estimated that there were about 5000 Justices, as opposed to just 12 Assize Judges, in 18 $18^{\text {th }}$ Century England. ${ }^{16}$ ) Notwithstanding the recognition, particularly in London, of the disadvantages of this discretionary and dis-organised 'system' as early as the late $17^{\text {th }}$ Century, ${ }^{17}$ the dynamics of criminalization were shaped to a yet greater extent than today by nonofficial actors right through to the $19^{\text {th }}$ Century. In trying to reconstruct how their decisions were made, and the broader context in which criminalization took place, literary resources are a useful supplement to contemporary pamphlets, case reports and court records - as recent work by scholars like Dana Rabin, Martin Wiener and Lisa Rodensky has shown. ${ }^{18}$

A second, more specific reason for examining the literary development of women's agency and responsibility lies in a fascinating current debate between historians of crime and punishment about levels of female criminality. In the turbulent history of criminal justice, most criminologists would agree that one of the few constants, across widely divergent societies, is the relatively low

\footnotetext{
${ }^{13}$ In what follows, I am drawing in particular on J. M. Beattie, Crime and the Courts in England 1660-1800 (Princeton, NJ: Princeton University Press, 1986) and his 'Scales of Justice' (1991) 9 Law and History Review 221; P. King, Crime, Justice and Discretion 1740-1820 (Oxford: OUP, 2000) and Crime and Law in England 1750-1840 (Cambridge: CUP, 2006).

${ }^{14}$ See in particular Jonathan Wild (1743, Oxford: Oxford World's Classics, 2003).

15 J. H. Langbein, The Origins of Adversary Criminal Trial (Oxford: OUP, 2003).

${ }^{16}$ See B. Lenman and G. Parker, 'The State, the Community and Criminal Law in Early Modern Europe', in V.A.C. Gatrell, B. Lenman and G. Parker (eds.), Crime and the Law (London: Europa, 1980) 32; see also King, Crime and Law in England $\mathrm{n} 13$ above, 47-50.

${ }^{17}$ Beattie, n 13 above, 621-624; n 15 above, Chapter 3.

${ }^{18}$ See M. Wiener, Reconstructing the Criminal (Cambridge: CUP, 1991); D. Y. Rabin, Identity, Crime, and Legal Responsibility in Eighteenth-Century England (New York: Palgrave Macmillan, 2004); L. Rodensky, The Crime in Mind: Criminal Responsibility and the Victorian Novel (Oxford: OUP, 2003); see also P. Collins, Dickens and Crime (London: Macmillan, 2nd edition, 1965); P. Brooks, The Melodramatic Imagination (New York: Columbia University Press, 1985) and Troubling Confessions: Speaking Guilt in Law and Literature (Chicago: University of Chicago Press, 2000).
} 
representation of women among those accused and convicted of crime. ${ }^{19}$ Though the assessment of crime figures before the inception of public statistics in the early $19^{\text {th }}$ Century is a notoriously tricky matter, the gradual accretion of historical research on local records now allows for some estimates. These suggest, in England, women made up a relatively small minority of offenders officially proceeded against from at least the $14^{\text {th }}$ Century on. ${ }^{20}$ The degree to which the recorded difference reflects specificities of women's behaviour as opposed to different response to female and male conduct has, of course been debated. And, reflecting the different poles of this debate, the official 'under-representation' of women has in turn been 'explained' in terms of, on the one hand, assertions of female passivity, weakness, incapacity, lack of opportunity, strong socialization to conformity or powerlessness, and, on the other, claims about leniency or 'chivalry' towards women. ${ }^{21}$

In 1981, however, Malcolm Feeley and Deborah Little published what has become an influential paper on the 'Vanishing Female: the decline of women in the criminal process 1687-1912'.22 The paper presented figures from the Old Bailey (London's principal criminal court) which suggested that the proportion of women charged with felonies dropped from, on average, a hefty $40 \%$ in 1680 to a mere $10 \%$ by the end of the $19^{\text {th }}$ Century. In the first decade of the $18^{\text {th }}$ Century, women even outnumbered men as defendants at the Old Bailey. ${ }^{23}$ Feeley and Little charted a relatively steady decline from the early $18^{\text {th }}$ Century, albeit punctuated by spikes related to specific social conditions such as war or economic disruption. Similarly high levels of female crime in the late $17^{\text {th }}$ and early $18^{\text {th }}$ Centuries have been reported by other historians working on Cheshire and on the North East of England, ${ }^{24}$ while John Beattie's Surrey data ${ }^{25}$ also confirms a higher (though less striking) proportion of female property offenders in the areas nearest to London. On the basis of this evidence, the plausibility of Moll Flanders in the early $18^{\text {th }}$ Century, succeeded by her literary unthinkability by its close, would seem to map on to a real decline in the recorded criminality of women.

${ }^{19}$ D. Elliot, Gender, Delinquency and Society (Aldershot, Avebury, 1988) Chapter 1; Morris, n 3 above, 18-19.

${ }^{20} \mathrm{~J}$. Kermode and G. Walker (eds.) Women, Crime and the Courts in Early Modern England (London: UCL Press, 1994) 4. As Kermode and Walker note, however, these estimates must be treated with caution, not least because of the male orientation of offence categories.

${ }^{21}$ For an overview of these theories, see Smart, $\mathrm{n} 3$ above; in relation to the $18^{\text {th }}$ and $19^{\text {th }}$ Centuries, see, respectively, King, Crime and Law in England $\mathrm{n} 13$ above, Chapters 5 and 6, and M. Wiener, Men of Blood: Violence, Manliness and Criminal Justice in Victorian England (Cambridge: CUP, 2004), Chapter 4.

22 At (1981) 25 Law and Society Review 719; see also M. Feeley, 'The Decline of Women in the Criminal Process: A Comparative History' (1994) 15 Criminal Justice History 235.

${ }^{23}$ By contrast, women made up only an eighth of prosecutors and victims at the Old Bailey between 1674 and 1834 - a fact which may speak to the difficult economic situation of women, and of single women in particular, in London: see further below, text from note 103.

${ }^{24}$ See, respectively, G. Walker, 'Women, Theft and the World of Stolen Goods' in n 20 above (women as $38 \%$ of theft defendants in 1660s Cheshire); n 4 above, Chapter 5; G. Morgan and P. Rushton, Rogues, Thieves and the Rule of Law: the problem of law enforcement in north-east England, 1718-1800 (London: UCL Press 1998), Chapter 3 (women over 50\% of those charged with theft in Newcastle, and at least a third over the whole North East region).

25 J.M. Beattie, 'The Criminality of Women in Eighteenth Century England' (1975) 8 Journal of Social History 80. 
More recently, however, Peter King has challenged Feeley and Little's interpretation, ${ }^{26}$ arguing that data from a variety of regions suggest no significant change in the proportion of female offenders between the mid-18 th and mid-19th Centuries. Further arguments calling the 'vanishing female' hypothesis into question are that inclusion of data on the less serious cases heard at Quarter Sessions would generate less striking results; that Feeley and Little's overall trajectory is distorted by the fact that their figures begin during what is generally acknowledged to have been an exceptional period; and that in any case the relatively high proportions of women recorded in the last decades of the $17^{\text {th }}$ Century and the very early $18^{\text {th }}$ Century (abutting, incidentally, the period in which Defoe locates Moll Flanders) were mostly to be found in London and other urban areas.

To come to a decisive view of the rights and wrongs of this debate would be beyond the scope of this paper. But I hope to illuminate some of the questions at issue by re-examining it in the light of both literary sources and historical data about women's changing social position. The strikingly high proportion of women prosecuted at the Old Bailey in the late 17th and early 18 th Centuries must have some significance; and the juxtaposition of this focus on women's criminality with the appearance of Moll Flanders is suggestive. What do the attitudes to women represented in literature - attitudes to their autonomy, capacity for responsibility, and social role - suggest about their likely treatment in the criminal process, and how do these match up with what we know about women's position in contemporary economy and society?

\section{CONDUCT, CHARACTER AND RESPONSIBILITY IN $18^{\mathrm{TH}}$ CENTURY CRIMINAL JUSTICE}

In what follows, I will draw on a set of hypotheses about the broad development of ideas of responsibility for crime which I have mapped out and defended in greater detail elsewhere, and for which I will offer only a sketchy justification here. ${ }^{27} \mathrm{My}$ starting assumption is that specific patterns of responsibility-attribution relate to various roles and needs of a criminal justice system: a need for legitimation, and a practical need to specify and coordinate the sorts of knowledge which can be brought into a court room. The imperatives set by these needs for legitimation and coordination are, needless to say, changing over time, as the

26 See King, Crime and Law in England 1750-1840 n 13 above, Chapter 6 and, advancing a more general argument about the relatively lenient treatment of women over the period of his study, including an estimate that men were $25 \%$ less likely to be acquitted, Chapter 5; see also King, Crime, Justice and Discretion 1740-1820 n 13 above, 196-207; J. M. Beattie, Policing and Punishment in London 1660-1750: Urban Crime and the Limits of Terror (Oxford: OUP, 2001) 20, 56, 63-72, 335-7, 356.

27 See in particular N. Lacey, 'In Search of the Responsible Subject: History, Philosophy and Criminal Law Theory' (2001) 64 Modern Law Review 350; 'Responsibility and Modernity in Criminal Law' (2001) 9 Journal of Political Philosophy 249. 
political, cultural, economic and institutional environment of the criminal process shifts. In the early $18^{\text {th }}$ Century, most criminal trials were a highly non-technical affair: a conversation between the accused and the court - trial, as John Langbein has put it, as altercation..$^{28}$ Levels of lawyers' involvement - with the important exception of treason trials and certain other highly technical areas such as forgery - were low: felony defendants had no right to be represented by Counsel until 1836, and though judges were increasingly exercising their discretion to allow counsel to engage in examination of witnesses from the middle of the $18^{\text {th }}$ Century, they had no right to address the jury until the passage of the 1836 legislation. ${ }^{29}$ The average length of a criminal trial in the last decades of the $18^{\text {th }}$ Century has been estimated at about 20 minutes, with Assizes hearing between 20 and 30 cases a day. This fact in turn lends weight to the judgment of one of the most influential historians of the period that the criminal trial operated up to the early $19^{\text {th }}$ Century on something far closer to a presumption of guilt than a presumption of innocence (a doctrine which, like the special criminal standard of proof, in any case received no judicial formulation until the late $18^{\text {th }}$ century). ${ }^{30}$

While treatises and commentaries on criminal law and its doctrines had of course existed for several centuries, their impact on run-of the mill cases can all too easily be over-estimated. Until well into the $19^{\text {th }}$ Century, there was no systematic law reporting, nor was there any regular system of appeals through which points of law could be tested until 1908. ${ }^{31}$ The law of evidence was still developing throughout the period, and the overwhelming bulk of evidence was either eye-witness testimony or evidence as to the defendant's or complainant's character and reputation. This evidence was focused on the accused's reputation and social position, but inferences about disposition appear to have been a natural corollary. Since the accused's confrontation with the jury was the kernel of the trial, wherever direct evidence of conduct was ambiguous, the jury's assumptions about his or her character (and that of witnesses) were central to the chances of exculpation: to judgments of credibility, to the reception of pleas for mercy, and to

\footnotetext{
${ }^{28} \mathrm{n} 15$ above.

29 This particular institutional arrangement itself drew the critical eye of novelists, including George Eliot: see Felix Holt: The Radical (1866, Penguin Classic, 1995) 367.

30 See further ibid 263, J.H. Langbein, 'Shaping the Eighteenth Century Criminal Trial: A View from the Ryder Sources' (1983) 50 University of Chicago Law Review, 82ff; and 'the Criminal Trial before the Lawyers' (1978) 45 University of Chicago Law Review, 236; see also Beattie, n 13 above 630; and Rabin, n 18 above,29. Even in late $19^{\text {th }}$ Century Kent, Conley found the presumption of innocence operating largely in favour of the respectable: C. A. Conley, The Unwritten Law: Criminal Justice in Victorian Kent (Oxford: OUP, 1991) $57 \mathrm{ff}$.

31 On the diffusion of knowledge about legal decisions during this period, and on the limited possibilities for appeal, particularly from Quarter Sessions, see King, Crime and Law in England n 13 above Chapter 1, esp. at $14 \mathrm{ff}$ and $32 \mathrm{ff}$. In relation to assize cases, before the creation of the Court for Crown Cases Reserved in the mid-19th Century, difficult cases might be referred to colleagues on a Judge's return to London; but neither this nor the CCR amounted to a systematic appellate process of the sort regarded, from the $20^{\text {th }}$ Century on, as central to a precedent-based system.
} 
the likelihood of partial verdicts: all crucial matters in a trial often focused on the key question of whether the death penalty would apply or not. ${ }^{32}$

One wonders, for example, how dispassionately the jury was able to assess the credibility of a certain Joseph Howells, otherwise known - as the heading to the report in the Old Bailey Sessions Papers records - as 'Lying Joe'. It seems likely that his conviction for Grand Larceny on October $16^{\text {th }} 1745$ was more or less assured when one of the witnesses gave the following testimony: 'I went to a publick house to enquire after him, and described him; and there was a man with a black cap and a chew of tobacco in his mouth, and he said he knew him, and that he_went by the name of Lying Joe, and was as great a villain as any in England, then I thought I should lose my money. ${ }^{33}$ (The unfortunate Joe was accordingly sentenced to transportation.) Another good example is Dorothy Copping, tried in 1688 for coining, 'as having a File, a pair of Cutting Sheers, and some Clipping found about her. Upon whose Tryal it was evident, That she had often [had] Clipped Monies, and brag'd of the quantities she had put off; and there being furthermore a Shilling new Clipped in her possession, though she alleged she found it, and that her Employ was to carry Loads as a Basket Woman; yet upon the Character given of her, the Jury found her Guilty of the Trespass. ${ }^{34}$ Conversely Sarah Hill, indicted for theft of valuable silver in 1696, was able to rely on evidence of good character: 'It appeared upon the Trial that her Husband had left the silver with her, who is since fled. She called abundance of People to her Reputation, who gave a very good Character of her, but said that her Husband was a very ill liver. The Jury taking it into Consideration acquitted her. ${ }^{35}$ As late as 1830, Richard Perrara, convicted of theft, was 'recommended to mercy by the jury on account of his character, and believing him to have been seduced by Griffiths' (his female co-defendant). ${ }^{36}$

Character evidence was also central to the pre- and post-trial processes, which formed a yet more influential aspect of the practice of criminalization in the $18^{\text {th }}$ and early $19^{\text {th }}$ Centuries than they do today. In filtering cases for trial, the Grand Jury would draw on local knowledge of the defendant's reputation, feeding into the assumption that those selected for trial were guilty. And in the elaborate and equally discretionary process of considering pleas for reprieve from the death penalty or pardons, ${ }^{37}$ those without people able and willing to testify to their

\footnotetext{
32 Beattie, 'Scales of Justice' n 13 above, 231-2; see also Rabin, n 18 above, 18 (a book which in my view overplays the impact of legal doctrines). As the trial scenes in both Felix Holt (n 25 above, 440-ff) and Elizabeth Gaskell's Mary Barton (1859, Penguin Classics with an introduction by Stephen Gill, 1980) demonstrate, character evidence still loomed large in the first half of $19^{\text {th }}$ Century, but its power was diminishing, just as the inferences which could be drawn from it legally were gradually reduced.

33 Old Bailey Sessions Papers T17451016-7.

34 Old Bailey Sessions Papers T16881205-25, 5 December 1688

35 Old Bailey Sessions Papers T16960909-23, 9 September 1696; cf. Jane Collins, acquitted on 13 January 1716 T17160113-44.

36 Old Bailey Sessions Papers T18300415-140: note that the court had no difficulty in ascribing primary agency to his female co-defendant.

${ }^{37}$ See King, Crime, Justice and Discretion above n 13, Chapter 9; V.A.C. Gatrell, The Hanging Tree: Execution and the English People (Oxford: OUP, 1994).
} 
character stood little chance of success - a fact which explains the special disabilities under which itinerant workers and migrants to urban areas laboured. ${ }^{38}$ On the other side of the coin, the strong reliance on both formal and informal mechanisms of social control on networks of information about reputation help to explain the persistent elite concern with vagrancy. It also helps to explain why the figures show distinctive patterns of criminalization in the cities, where networks of communication and reputation were less robust, and hence a less potent resource for the criminal process. In this context, a functional presumption of guilt became a particularly important resource for the system: the defendant who was unable to produce evidence rebutting an inference of bad character would be convicted. Even in the second half of the $18^{\text {th }}$ Century, when urbanization was developing apace, it is crucial to realize that levels of mobility were still relatively low, while media of communication through the rapidly developing Press, along with rising literacy rates, allowed for the diffusion of advertisements and the pursuit of offenders across strikingly large areas. John Fielding, the influential mid-century London magistrate and reformer, used this to good advantage by instituting a system of sending descriptions of offenders wanted in London as far afield as the North East, from which records show that a significant number of suspects were returned. ${ }^{39}$

To today's criminal lawyer, beyond its highly discretionary nature and the spectacular features of the 'Bloody Code' which threatened (though much more rarely exacted) the death penalty for a vast range of even minor property offences, perhaps the most striking aspect of the $18^{\text {th }}$ Century criminal process was the fact that it appears to have operated quite effectively without anything approaching the technical doctrines of responsibility-attribution which form the backbone of criminal law today. Today, the state's responsibility to prove not only criminal conduct but individual responsibility for that conduct lies at the heart of criminal law's legitimation as a system of justice rather than one of sheer force: the fairness of criminalization and punishment is fundamentally premised on the idea that an offender's capacities of understanding, awareness and self-control were engaged at the time of the alleged offence. In the $18^{\text {th }}$ Century, by contrast, though culpability requirements such as having acted 'maliciously', 'wickedly', 'feloniously' or 'animus furandi' had long been discussed by commentators and asserted by judges as aspects of many common law offences, these were very far from equating to the psychological and capacity-based requirements of 'mens rea' with which we are familiar today. ${ }^{40}$ Nor, in the light of the features already mentioned - speed of trial, lack of legal argumentation - could the $18^{\text {th }}$ Century trial process have managed evidence of such 'mens rea' as a formal object of proof.

38 On the greater reluctance to show leniency to those not members of the immediate community, see King, Crime, Justice and Discretion above n 13, 183-91.

${ }^{39}$ Morgan and Rushton, n 24 above, Chapter 2

${ }^{40}$ See J. Horder, 'Two Histories and Four Hidden Principles of Mens Rea' (1997) 113 Law Quarterly Review 95. 
How, then, did the system work? Beyond a baseline assumption of capacity (which could be displaced by evidence of manifest insanity), the trial was firmly focused on conduct. Where evidence about conduct was questionable, the patterns of attribution based on local knowledge about character and reputation which dominated the pre-trial process also informed the trial itself. In effect, a judgment of criminal responsibility was a judgment of bad character - or, perhaps more accurately, proceeded on the basis of a default assumption of bad character which could on occasion be rebutted by convincing evidence of good character. ${ }^{41}$ The need for the jury to assess the defendant's credibility as a witness was at the core of the resistance to allowing representation by counsel. The bulk of $18^{\text {th }}$ Century criminal trials were not driven primarily by criminal law: rather, they involved a very human process of judgment, shaped by prevailing cultural assumptions about guilt and innocence, good and evil, sanity and madness, credibility and unreliability. Notwithstanding the radical reconstruction of the criminal process in the first half of the 19th Century - the abolition of the capital statutes, the creation of the police, the consolidation of the law of evidence and so on - the legal doctrine of capacity-based individual responsibility as an object of proof in the court room was still developing right through to the mid-20th Century - a much slower process than has been assumed by many historians of criminal law. ${ }^{42}$

The treatment of what we would today call mental incapacity defences is particularly instructive here, for it illustrates that even when matters of capacity were before $18^{\text {th }}$ Century criminal courts, their handling was very different from that which a modern lawyer might expect. There was no statutory recognition of an insanity defence until 1800, and no elaborated common law definition of insanity until the McNaghten rules were formulated in 1843.43 Of course - as remains the case today - many insane defendants would have been filtered out of the criminal process long before they came to trial; but, as records show, cases of insanity did reach the courts from time to time. When they did, their disposal was shaped by common-sense jury assumptions about madness and its implications for culpability. This is reflected in some very matter of fact reports. In 1710, 'Mary Bradshaw alias Seymour, of St. Giles's without Cripplegate was indicted for feloniously stealing 2 Stuff Gowns, Value 20 s. a Stuff Petticoat 3 s. with other things, the Goods of Elizabeth Morgan. A Cloth Petticoat 5 s. a Stuff Peticoat 3 s. 3 Dowlace Smocks $15 \mathrm{~s}$. the Goods of Anne Downing. The Fact was plainly prov'd upon the Prisoner; but sufficient Proof being given in Court that she was an Idiot, the Jury acquitted her.'. ${ }^{44}$ Even in the case of much more serious charges, a similar tone prevails, as in the case of Susannah Jones, charged in 1740 with the murder of a child: 'Samuel Tuttle gave the same Account, and added, that the

${ }^{41}$ See N. Lacey, 'Character, Capacity, Outcome: Towards a framework for assessing the shifting pattern of criminal responsibility in modern English law', in M. Dubber and L. Farmer (eds.) Modern Histories of Crime and Punishment (Stanford: Stanford University Press, 2007).

${ }^{42}$ See for example K.J.M. Smith, Lanyers, Legislators and Theorists (Oxford: Clarendon Press 1998).

${ }^{43}$ M'Naghten's Case (1843) 10 Clarke and Finnelly 200, 8 Eng. Rep. 718 (1843).

44 Old Bailey Sessions Papers T171011206-22, 17 December 1710. 
Prisoner told him, she thought somebody spoke to her, and bid her do it; and that she acknowledg'd, she took the Child out of the Cradle with an Intent to kill it, but having some Remorse, she laid it down again; but in a few Minutes it crying vehemently, she took it up again, and cut it's Throat with the Razor, which she afterwards laid in the Corner of the Window. Her Confession (to this Purpose) before Colonel De Veil , was read in Court, but Anthony Benn and Robert Benn, giving the Prisoner the Character of a sober, well-behav'd Girl, not addicted to Cruelty; and Elizabeth Sanders speaking to some Symptoms of a disorder'd Mind in the Prisoner, the Jury acquitted her, and found her Lunatick .'45

This is not to say that juries or witnesses were undiscerning. One witness in the case of Elizabeth White, tried for theft in 1745, commented, 'She is more politick than mad. She is more knave than fool.' ${ }^{36}$ White was duly convicted. As Arlie Loughnan has argued, ${ }^{47}$ the prevailing pattern here was - echoing George Fletcher's famous notion of 'manifest criminality'48 - a pattern of 'manifest madness': insanity was simply what a jury recognized as such. Fielding, an early advocate of modernization and systematization in criminal justice, was quick to satirize the indeterminacy which must occasionally have resulted. In Tom Jones, he comments "Who knows what may be sufficient evidence of madness to a jury?... Madness was sometimes a difficult matter for a jury to decide; for I remember... I was once present at trial of madness, where twenty witnesses swore that the person was as mad as a march hare; and twenty others that he was as much in his senses as any man in England.... ${ }^{49}$ But if such intractable disagreements had often troubled $18^{\text {th }}$ Century juries, it seems likely that pressure for change would have come far sooner than it did.

In this rather fluid legal context, as Dana Rabin has shown in a fascinating recent book, prevailing cultural influences had a decisive and direct effect upon legal practices. ${ }^{50}$ She marshalls evidence that the emerging culture of sensibility in the $18^{\text {th }}$ Century prompted defendants to push the boundaries of what had conventionally been understood as insanity in the direction of accommodation of a wide variety of states of emotional distress. This process was ultimately seen as threatening to the integrity of the law's prohibitions, and was accordingly closed off through the increasingly technical specification of the conditions for the

45 Old Bailey Sessions Papers T17400116-49, 16 January 1740; cf the case of 'Elizabeth Collins, widow...indicted for stealing one shagreen case, value $2 \mathrm{~s} .12$ knives with silver handles, value $10 \mathrm{~s}$. and 12 forks with silver handles, value 6 s. the property of Henry Crow, doctor in physic, August 28. The prisoner's behaviour at the bar, and while in confinement, as appeared by Mr. Akerman's servants, discovered her to be insane.' (Old Bailey Sessions Papers T17660903-7). Like about half of those raising insanity defences, she was acquitted.

46 Old Bailey Sessions Papers T17451016-5, 16 October 1745.

47 A. Loughnan, 'Manifest Madness' (2007) 68 Modern Law Review 379; see also R. Smith, Trial by Medicine: Insanity and Responsibility in Victorian Trials (Edinburgh: Edinburgh University Press, 1981), Chapter 7 of which illustrates that even in the 19th Century, non-technical assumptions about female insanity continued to inform the trial process, with infanticide cases in particular often tried without medical evidence being led.

48 See his Rethinking Criminal Law (Boston and Toronto: Little, Brown, 1978)

49 Tom Jones (1749, Oxford: Oxford World Classics, 1996), 562-3.

${ }^{50}$ Rabin, n 18 above. 
insanity defence being developed in case law from the early $19^{\text {th }}$ Century on. As Rabin also notes, the $18^{\text {th }}$ Century cases display what is to our eyes a strange blurring of the concepts of criminal intention and character. ${ }^{51}$ The operative assumption, I would argue, was that the defendant's conduct exhibited or expressed bad character: this was a holistic judgment of wrongful conduct and dangerousness rather than today's supposed analytical separation of conduct from 'mens rea'. The trial afforded the defendant the opportunity exculpating him- or her-self - and indeed it was out of these developing arguments about defences that the elaborated doctrines of responsibility eventually emerged in the latter half of the 19th Century. Meanwhile, the key variable in most criminal trials was the defendant's capacity to gather together credible people willing to speak for her and back up her testimony. Even when the defendant's mental state were unavoidably at issue, attributions of responsibility were based, in short, on assumptions about the quality of character displayed in conduct, rather than on a careful investigation of the whether the defendant's cognitive and volitional capacities were fully engaged in the relevant action.

\section{THE ROLE OF 'CHARACTER' IN EIGHTEENTH AND NINETEENTH CENTURY NOVELS}

It was the need further to investigate the cultural roots of the ideas of 'character' which I see as so central to the operation of $18^{\text {th }}$ Century criminal justice which first propelled me towards the corpus of literary fiction. I was aware that there existed among literary scholars and historians a lively debate about the shape and influence of notions of 'character' in both centuries, and I assumed that there would be interesting evidence about the circulation of these ideas within the novels. This was, after all, the era in which the 'realist' novel was developing. ${ }^{52}$

\footnotetext{
51 ibid Chapter 3; see also p.160.

52 Of course, realist novels were not the only influential genre: think of the fascinating $18^{\text {th }}$ Century satires, the 'gothic' novels of the late $18^{\text {th }}$ Century; $19^{\text {th }}$ Century melodrama; comedies of manners. Nor did 'realism' take the same form across this long period: the classics of $19^{\text {th }}$ Century realism, perhaps epitomized by G. Eliot's Middlemarch (1871-2, Penguin Classics, 1994), are of a different order from the more formulaic narratives of Defoe, Richardson, Burney, Smollett or Fielding, just as Thackeray's epic realism of types in Vanity Fair differs from Romanticism or from the more deeply psychological individualism of George Eliot. And yet - as the protestations of many of the earlier authors, including Defoe, Richardson and Fielding, show, there was in all these works an ambition to represent or write from life. (See for example Samuel Richardson, Pamela (1740, Penguin Classics, 1985), Richardson's preface, xx; Henry Fielding, Joseph Andrews, (1742, Penguin Classics, 1999), 203; n 49 above, 648. Moll Flanders and Roxana were written as pretended autobiographies, with frequent references by an anonymous 'editor' to the 'fact' that the style has been changed only to the limited extent necessary to aid comprehension, in the interests of authenticity.) The genre may have varied: from supposed autobiography and epistolary novels through romping epics to the magisterial voice of the all-seeing third person narrator of the $19^{\text {th }}$ Century: but the books are all informed by an aspiration to illuminate certain truths about human nature and observations about social structure. In this respect, Hardy's caustic response to the public criticism (n 8 above) which met the publication of Tess of the d'Urbervilles is instructive; 'I will just add that the story is sent out in all sincerity of purpose, as an attempt to give artistic
} 
A further motivation was the promise which the novels held out of illuminating what the abstract ideas circulating in contemporary philosophy - or philosophy being widely read at the time - meant in terms of people's views of human motivations, dispositions and relation to the social world. ${ }^{33}$ Debates about free will versus determinism; about the essential goodness or reformability - or otherwise - of human beings; about the role of environment in producing character and conduct; about individual responsibility and autonomy; about the capacity to amend or 'work on' one's character; about the very stability of human character: all these abound in the novels, alongside fascinating insights into contemporary social and political preoccupations - fears about the corrupting and de-moralising influence of urbanization key among them.

My initial strategy was to chart appeals to the idea of 'character' in a selection of novels, tracing the different inflections at work and the use to which they were being put. I very quickly began to realize the scale of the task. In $18^{\text {th }}$ Century novels like Moll Flanders, Pamela, Clarissa, Tom Jones or Cecilia, references to character appear on virtually every other page. A number of more or less distinct inflections can be discerned, moving on a spectrum from character as role, type or status at one end ('he thought a Schoolmaster the greatest Character in the world'54 or 'a leading man in the House of Commons is a very important character'55); through notions of character as reputation ('the Character I was ambitious of attaining, was that of a fine Gentleman...'56: this reputational sense relates to a more specific sense of 'character' as reference or testimonial, as in 'dismissed without a character'); moving on to character as moral standing or as disposition ('This Shyness... will recommend her Character to all our Female Readers... ${ }^{57}$ ), through to character as individual psychological traits or personality ('her character was totally insipid' ${ }^{58}$ ). Often references move between these nuances, playing on the ambiguity: 'the ridicule I should meet with below upon a weakness so much out of my usual character'. ${ }^{59}$

form to a true sequence of things; and in respect of the book's opinions and sentiments, I would ask any too genteel reader, who cannot endure to have said what everybody nowadays thinks and feels, to remember a well-worn sentence of St. Jerome's: 'If an offense come out of the truth, better is it that the offense come than that the truth be concealed.' (Explanatory Note to the First Edition, November 1891) A kernel of realism is also to be found in many satires and comedies of manners - think of Thackeray's regular asides in Vanity Fair about the human predicament and dispositions, or of Swift's deployment in Gulliver's Travels (1726, Penguin Classics, 2001) of imaginary worlds as a perspective for commentary on his own.

53 The ideas about human nature and understanding emerging from the Enlightenment philosophies of figures like Locke and Hume, along with older ideas about character and virtue in Aristotle and Plato, as well as Spinozist ideas about determinism, and a panoply of ideas from various Christian traditions, are all to be found, more or less explicit, in the novels, and provide further clues to the complex and fastshifting cultural world in which modern practices of criminalization were developing.

${ }^{54}$ Fielding, $\mathrm{n} 52$ above, 238.

${ }^{55}$ Clarissa (1747-8, Boston: Houghton Mifflin, abridged version Riverside editions, 1962) 248.

${ }^{56}$ Fielding, $\mathrm{n} 52$ above, 214.

${ }^{57}$ Fielding, n 52 above, 166.

58 Tobias Smollett, The Expedition of Humphry Clinker (1771, Oxford: Oxford World's Classics, 1998) 266.

${ }^{59}$ n 55 above, 265 
To paint with very broad brush strokes, in the novels there is a discernible shift in terms of frequency and emphasis from references to character as social type or public role through character as social reputation to character as disposition and finally as psychological makeup as we move from the earliest novels of Defoe, Richardson and Fielding to the novels of the late $18^{\text {th }}$ and early $19^{\text {th }}$ Century. Overall, the concept of character is less prominent as we move into the $19^{\text {th }}$ Century, is often focused on personality and psychological disposition, and is rarely concerned with social role or type. The reputational senses of character, including the technical sense of character as testimonial, remain important - a significant finding when we consider that the centralizing and systematizing criminal justice reforms of the $19^{\text {th }}$ Century developed slowly over many decades, and left intact a large degree of local autonomy which at least in certain rural areas continued to underpin significant regional variation and resort to informal justice. ${ }^{60} \mathrm{~A}$ telling example here is V anity Fair, published in 1847-8, but set in the earlier period of the Regency, and a book in which the ruthless, beautiful and talented Becky Sharp is set up as the foil to expose the shallowness of a world obsessed with marks of status and reputation yet in which it is in fact money and power which buy respect. I shall return later to consider the anxieties about the 'corrupting' influence of social changes such as urbanization and the development of the bourgeoisie on traditional ideas of moral character which surface frequently in the novels.

The centrality of 'character' in the $18^{\text {th }}$ Century novels attests to the extraordinary importance of public reputation in a relatively immobile world. This centrality echoes the way in which the $18^{\text {th }}$ Century criminal process was able to draw, for the purposes of legitimation and practical coordination or judgment, on widely shared assumptions and preoccupations diffused across $18^{\text {th }}$ Century society, as well as on networks of communication which made the resultant knowledge available to the criminal process. Fielding gives us a delicious glimpse of this world - and of its attendant pitfalls - in Joseph Andrews. ${ }^{61}$ The morally impeccable (and gloriously absent-minded) Rev. Abraham Adams and his young friend Fanny Goodwill are arraigned before a Justice for assault, in circumstances in which in fact Adams had been rescuing Fanny from assault by a third party. The local Justice is keen to get matters over in highly summary fashion on the basis of evidently trumped up testimony: his inclination to commit Adams to goal, and to see 'if you can prove your Innocence at Size...' illustrates both the functional burden of proof against the defendant and $18^{\text {th }}$ Century magistrates' developing habit of committing suspects to goal for further examination without any clear legal mandate for so doing. ${ }^{62}$ At this point, in Fielding's words; 'One of the Company having looked stedfastly at Adams, asked him, 'if he did not know Lady Booby?'. Upon which Adams presently calling him to mind, answered in a

${ }^{60}$ Conley, n 30 above.

${ }^{61}$ Fielding, n 52 above, 168-70.

${ }^{62}$ See King, Crime and Law in England $\mathrm{n} 13$ above, Chapter 1, 44-46. 
Rapture, 'O Squire, are you there? I believe you will inform his Worship I am innocent.' 'I can indeed say,' replied the Squire,' that I am very much surprised to see you in this Situation;' and then addressing himself to the Justice, he said, 'Sir, I assure you Mr Adams is a Clergyman as he appears, and a Gentleman of a very good Character. I wish you would enquire a little farther into this Affair: for I am convinced of his Innocence.'; 'Nay', says the Justice, 'if he is a Gentleman, and you are sure he is innocent, I don't desire to commit him, not I; I will commit the woman by herself, and take your Bail for the Gentleman...'. Adams then intercedes for Fanny, is listened to, and prevails, not least because the lying witness, seeing the turn of the tide, has absconded.

Here we see, in effect, an inference from character as reputation to conduct in contrast to the inverse $19^{\text {th }}$ Century inference from conduct to character, in the sense of disposition. The centrality of reputation to $18^{\text {th }}$ Century society is underlined in the novels by the use of striking metaphors either personifying character or rendering it as valuable property. In Smollett's Expedition of Humphry Clinker, one figure protests, 'don't go to murder my character', while another is described as 'bankrupt, both in means and reputation.'.63 And in Tom Jones, Fielding argues that 'to murder one's own reputation is a kind of suicide', and quotes from Othello:

'Who steals my purse steals trash; 'tis something, nothing';

Twas mine, 'tis his, and hath been slave to thousands;'

But he that filches from me my good name

Robs me of that WHICH NOT ENRICHES HIM

BUT MAKES ME POOR INDEED. ${ }^{64}$

Yet the change in conceptual framework between the $18^{\text {th }}$ and the $19^{\text {th }}$ Century novels does not connote a complete rupture in terms of deeper concerns.

References to character in the sense of public role may gradually disappear, but the later novels are nonetheless exploring many of the same issues about character as disposition: free will and determinism, the role of environment, the fixity and stability (or otherwise) of human personality. Just as Jane Austen made Sir Thomas Bertram agonise, at the end of Mansfield Park, ${ }^{65}$ on the role of a deficient upbringing in spoiling his daughter Maria's character, and as George Eliot comments in Middlemarc ${ }^{66} \mathrm{on}$ the role of an indulgent and undisciplined upbringing on Fred and Rosamond Vincy, and on the role of different gender expectations in shaping that impact variously on the two of them, so Richardson is already meditating on similar themes in mid-18 $8^{\text {th }}$ Century Clarissa. In her last letter

${ }^{63} \mathrm{n} 58$ above, 74 and 68-9; see also 103: 'As for the liberty of the press, like every other privilege, it must be restrained within certain bounds... If the lowest ruffian may stab your good-name with impunity in England, will you be so uncandid as to exclaim against Italy for the practice of common assassination? To what purpose is our property secured, if our moral character is left defenceless?

${ }^{64} \mathrm{n} 49$ above, 201, 493.

65 Mansfield Park (1814, Penguin Classics 1996) 419-420.

${ }^{66}$ Eliot n 52 above, for example, 328-9 and 647. 
to her father, the heroine - wronged by her family as much as by her seducer nonetheless thanks him for the upbringing which has taught her the path of virtue: '..let me bless you, my honoured papa.... for all the benefits I have received from your indulgence... for the virtuous education you gave me; and for the crown of all, the happy end, which, through Divine grace, by means of that virtuous education, I hope, by the time you will receive this, I shall have made.'. Similarly, her abductor Lovelace in a late letter to his friend Belford excoriates his mother for spoiling him 'Why, why did my mother bring me up to bear no control? Why was I so educated as that to my very tutors it was a request that I should not know what contradiction or disappointment was? Ought my mother not to have known what cruelty there was in her kindness?'. ${ }^{67}$

But whereas in the $18^{\text {th }}$ Century these issues are being investigated through the interplay of human beings who are very firmly located within particular social roles, and characterized as particular types, as we move into the $19^{\text {th }}$ Century, the investigation - facilitated, of course, by the invention of the all-seeing third person narrator - is focused on the interior world of increasingly richly described human psychologies. To the $21^{\text {st }}$ Century reader, the $18^{\text {th }}$ Century novels read almost like restoration comedies: key figures (including of course Moll Flanders) have names which evoke their dispositions and social position: Squire Booby, Fanny Goodwill, Squire Allworthy, Mrs Slipslop and so on. They are vivid, and many of them, like Moll, are thoroughly rational and agentic: but they are not fully realized psychological individuals in the style of Austen, Bronte, Eliot or Hardy. (No more, one might argue, were Dickens' similarly named caricatures, or most of the figures in Vanity Fair, with the gradual exception of the ultimately inaptly named Dobbin, whose depth of psychological development lifts the book from the status of a brilliant comedy of manners into a truly great realist novel).

The $18^{\text {th }}$ Century novels are, I would argue, reflecting a transition: a transition from a world in which notions of individual psychology are already apprehended as important - a world of dawning individualism; and yet a world in which that individualism is impossible to transcribe onto the status-based institutions of civil society. ${ }^{68}$ Here, Richardson's Clarissa is of particular interest. Clarissa is doomed the minute she leaves the protection of the family; her actual virtue cannot in normal social space survive the conventional ruin of her character. But there is modern individualism here too; for the more amiable characters recognise her virtue as triumphing over social forms; and it is this individual virtue which is upheld, within Richardson's religious message, as the object of our admiration and as, ultimately, triumphant. Similarly in Tom Jones we find Fielding reflecting critically on the social practice of judging individuals on the basis of received wisdom about their characters: 'A single bad act no more constitutes a villain in life than a single bad part on the stage. The passions, like the managers of a

${ }^{67} \mathrm{n} 55$ above, $482,499$.

${ }^{68}$ See the inability of the criminal justice system at this time to handle elaborated notions of capacitybased responsibility as an object of proof. 
playhouse, often force men upon parts without consulting their judgment, and sometimes without any regard to their talents. Thus the man, as well as the player, may condemn what he himself acts...'. ${ }^{99}$ And this Platonic sense of the duty to subject our passions to the constraint and critical tribunal of our reason relates in Fielding to a notion of the essential ambivalence of character, anticipating the idea of a duty to work on one's character which became so important to early $19^{\text {th }}$ Century criminal justice: 'few characters were so absolutely vicious as not to have the least mixture of good in them...' ${ }^{70}$

Beyond the specific deployment of ideas of character, also of interest from a criminal justice perspective is the way in which the $18^{\text {th }}$ Century novels exhibit prevailing social anxieties, particularly about the possible de-civilising and demoralising impact of urbanization and of increasing social mobility in the emerging individualistic world. The theme of the danger and corrupting influence of town life, and of access to too much readily disposable wealth, is a constant from Clarissa through Joseph Andrews and Tom Jones, to the ultimate status of London as the pinnacle of Vanity Fair. In Frances Burney's Cecilia ${ }^{11}$ London is the fount of self-interest, evil, temptation, deracination from a life of quiet connection and decency, while Mr. Matthew Bramble in Tobias Smollett's Humphrey Clinker constantly returns in his letters to the enjoyable practice of drawing an unfavourable comparison, in terms of civility and hygiene, between London and the country. ${ }^{72}$

Already in this book, published in 1771, we are witnessing an awareness of, and anxiety about, the breakdown of the conditions of existence of what had for long been a very stable basis of both legitimation and practical coordination in the criminal process and indeed in the social order more generally: relative value consensus, stable relations between social classes and readily available information about reputation key among them. Each of these conditions of social ordering and - of almost equal importance - faith in their vigour- were undoubtedly eroded by urbanization, by greater social mobility attendant on the growth of trade, and by the development of a capitalist economy. As we shall see, these anxieties were to have important implications for the criminalization of women. Of further significance here was the emergence of a bourgeois and merchant class (the primary audience for the emerging genre of the novel $)^{73}$ whose interests and values differed significantly from those of the landed elites, and of an urban working class untied from the rural social structures and quasi-feudal institutions which had proved such an effective source of informal social control (and which continued

\footnotetext{
69 n 49 above, 286. Fielding invites us to judge Tom as a decent and well-meaning individual notwithstanding his scapegrace behaviour - though it is convenient, and telling in terms of the novel's transitional position, that it turns out that he is, by birth, a gentleman.

70 ibid, 794: Fielding invokes both Platonic and Aristotelian ideas.

71 1782, Oxford: Oxford World Classics, 1999.

$72 \mathrm{On}$ anxieties about crime and disorder in London from the late $17^{\text {th }}$ Century, see Beattie, n 26 above, and see further below, text from note 103 .

73 See Watt, $\mathrm{n} 7$ above: in criminal justice as in politics, the ideas and values of this emerging bourgeoisie struggled for well over a century for institutional realisation.
} 
as such in rural areas well into the $19^{\text {th }}$ Century $\left.{ }^{74}\right)$. Gradually, the criminal process responded by beginning to develop ideas of responsibility which were relatively independent of the content of the norms breached, which could be proven - once the relevant institutions were put in place - in the trial forum, and which could be controlled by professionals rather than by a jury. But this development took many decades to accomplish, just as the construction of a code of public morality adequate to disciplining the forces unleashed by capitalist culture has been a long time in the making (if indeed it has yet been accomplished). Part of the cultural perplexity which animates Moll Flanders is, as Juliet Mitchell put it, 'a question of the similarity of the crimes and the laws against them, of 'acceptable society' and its 'underside? 75

\section{CHARACTER, CRIMINALITY AND AUTONOMY FROM MOLL TO TESS}

There is plenty of evidence, then, in the $18^{\text {th }}$ Century novels about character and reputation in the attribution of responsibility during that period. But, the light of Feeley's and Little's argument about 'the vanishing female' in mind, it is also interesting to consider the ways in which judgments of good and bad character were gendered. If responsibility-attribution was shifting slowly from the $18^{\text {th }}$ Century through the $19^{\text {th }}$ Century from a character-based to a capacity-based pattern, this might help to explain the gradual decline in women's recorded involvement in crime. If the association of criminal responsibility with proof of agency and capacity was growing stronger, gender patterns of responsibilityattribution might be changing. For the faculties of reason and self control in terms of which Enlightenment philosophy understood responsibility were themselves increasingly believed to be more liberally (as it were...) bestowed upon men - as Mary Wollstonecraft noted very clearly. ${ }^{76}$

The long-standing association of reason and intellect with masculinity, and of emotionality and the body with femininity, was arguably becoming reinforced by two further cultural developments. The first was the emergence from the mid- $18^{\text {th }}$ Century on, of an initially highly feminised culture of sensibility. ${ }^{77}$ This is exemplified by heroines like Clarissa, Cecilia and Fanny Price, while mercilessly satirized in Thackeray's shallow Amelia, whose sensibility is such that she can burst into tears at the mere thought of someone's suffering, yet who is incapable of understanding real love. The second was the gradual construction, from the

${ }^{74}$ Conley, $\mathrm{n} 30$ above.

75 Mitchell, $\mathrm{n} 2$ above, 204.

76 A Vindication of the Rights of Woman (1792, New York: Carol Poston, 1988).

77 On the establishment from the late $17^{\text {th }}$ Century of Societies for the Reformation of Manners, see Beattie, n 13 above 621-624, and n 26 above 54, 58, 61, 66, 237-238. 
early $19^{\text {th }}$ Century on, of Victorian family ideology which explicitly circumscribed the proper terrain over which women's activity and agency could be exercised. ${ }^{78}$

In the $18^{\text {th }}$ Century, judgments of good and bad character would of course have been gendered. But they might nonetheless have been susceptible of mobilisation as much for women as for men: what counted as good and bad character for men and women might be different, but each might suffice to underpin an attribution of criminal responsibility. This would have amounted, as Garthine Walker has put it in relation to the $17^{\text {th }}$ Century, to a situation of incommensurable rather than unequal principles of judgment. ${ }^{79}$ Indeed, there might even be reason to think that assumptions of bad character were particularly readily available in relation to women. Moll Flanders for example rails against the unfairness that it was normal for men to inquire into a woman's character and reputation but unseemly for a woman to do the same about a man's; she also notes the power of gossips to ruin male as well as female reputation (with typical resourcefulness, Moll exploits this circulation of reputation by manipulating it by propagating false information about her fortune to entrap her Lancashire husband). ${ }^{80}$

Moll's own criminality appears to reflect rather accurately what we know about female crime in the late $17^{\text {th }}$ Century. It often involved the theft of valuable textiles and other articles of domestic equipment; women were well represented among receivers and pawnbrokers; levels of female property crime in London were relatively high, and a cause of significant anxiety, and women tended to work either alone or with other women, rather than with men. ${ }^{81}$ Indeed, Moll's downfall is her impulsive decision to steal a horse: this being a form of thieving dominated by men, Moll had no access to the networks of trading which would have allowed her to dispose of the horse. ${ }^{82}$ Equally, literary observations about the role of women in policing reputation fits with emerging understandings of women's role in propagating social order in early modern England. Recent research has begun to reveal the relatively active part which women played, as litigants as well as witnesses and victims, even across such ostensibly inhospitable terrain as the administration of laws on witchcraft. ${ }^{83}$ With the gradual privatization of women in the Victorian era, and yet further with their supposed mental incapacities as socially determinist and biologistic theories of crime developed in the latter part of the $19^{\text {th }}$ Century, it has been argued that criminal justice became displaced, less necessary, as a mechanism of women's social control. As Feeley and Little put it,

${ }^{78}$ See Lucia Zedner, Women, Crime and Custody in Victorian England (Oxford: OUP, 1991) Chapter 1.

$79 \mathrm{n} 4$ above, Chapters 1, 5 (on property offences) and 7; see in particular the argument about incommensurability at 158 .

$80 \mathrm{n} 1$ above, 113-114; $115 \mathrm{ff}$.

${ }^{81}$ See Walker, n 24 above; n 25 above, 228.

82 See $n 4$ above, 167-168.

83 n 4 above, Chapter 6, which develops the theme of women's agency, their active deployment of the legal process in areas like resisting distraint of goods, in exercise of their household authority, and pursuing bastardy cases. Throughout the book, Walker demonstrates the inaccuracy of stereotypes of stable masculine and feminine treatment and behaviour. See also J. Sharpe, 'Women, Witchcraft and the Legal Process', Chapter 5 in n 20 above; and the editors' Introduction. 
the social, economic and cultural changes which accrued up to the late $19^{\text {th }}$ Century may have meant that 'women became less inclined and able than men to engage in activity defined as criminal, and women were less subject to the criminal sanction as other forms of more private control emerged. ${ }^{3} 84$

Conversely, even in the late $19^{\text {th }}$ Century, there is evidence to suggest that ideas of bad character remained especially significant to the treatment of women: the criminal statistics for 1890 show that $53 \%$ of men, as compared with only $35 \%$ of women before the courts were first offenders, while only $12 \%$ of women were recorded as being 'of good character'. ${ }^{85}$ And, even leaving aside King's criticism of Feeley and Little's interpretation of the facts, literary examples immediately pose some difficulties for any argument about the marginalization of women from emerging capacity-based principles of responsibility. For, though the novels bombard their reader with fascinating data on assumptions about women and their social position and capacity, most of the women who people the novels from Moll to Tess are recognizable agents with fully fledged rational capacities. From the very beginning of the genre, these women are utterly recognizable to the modern reader: they reason about values, consequences, strategies; they worry and feel; they hope and dare; on occasion they defy patriarchal authority even in the face of a clear-eyed analysis of the likely (usually grim...) upshot of doing so. They straddle, with insouciance, all the binaries to one side of which prevailing masculine culture (and some feminist theory) have aspired to confine them. As late as 1848, Thackeray juxtaposes Amelia's exaggerated female weakness and sensibility with the luminous autonomy and hard-headedness of Becky, as well as threading into the interstices of his novel some reflections on the distorting effects of prevailing discourses of femininity which evoke the arguments of some late $20^{\text {th }}$ Century feminists. Here is Thackeray: 'What do men know about women's martyrdom? We should go mad had we to endure the hundredth part of those daily pains which are meekly borne by many women. Ceaseless slavery meeting with no reward; constant gentleness and kindness met by cruelty as constant; love, labour patience, watchfulness without even so much as the acknowledgment of a good word; all this, how many of them have to bear in quiet, and appear abroad with cheerful faces as if they felt nothing. Tender slaves that they are, they must needs be hypocrites and weak. ${ }^{86}$ And here is Luce Irigaray, writing 150 years later: 'Men are uncivil as a result of too many rights and too few duties, and women as a result of too few rights and too many duties, for which they compensate by impulsiveness and subjectivity without social bounds, in the form of either persistent childish behaviour or maternal authoritarianism extending into the social sphere.' 87

$84 \mathrm{n} 22$ above, 741

${ }^{85}$ See $\mathrm{n} 78$ above, 22, 43.

${ }^{86} \mathrm{n} 11$ above, 663-664.

${ }^{87}$ See Luce Irigaray, Thinking the Difference (London: Athlone Press, 1994) 78; see also her comment at 82 about women's lack of public responsibilities leaving us (significantly, she says 'them') 'mired in instability, dissatisfaction, criticism.' 
But this is not to say that the literature has nothing to tell us about what might be driving changing patterns of female crime or perceptions of female criminal capacity. The crucial pointer here is not so much a growing vision of female incapacity but rather the subtly changing material position of women amid the relative decline of the agricultural economy in which they were relatively securely integrated, and amid the emerging culture of sensibility, which accorded them a leading role in the process of civilization and refinement of manners which was conceived as a counter to the corrupting effects of modernization and urbanization. This latter development issued in a whole series of changes in the treatment of women in criminal justice - the gradual (and without any legislative mandate) abandonment of public whipping of women during the $18^{\text {th }}$ Century significant among them. ${ }^{88}$ Increasingly, the role which is developing amid the culture of sensibility - an extension rather than a complete rupture with women's long-standing role in policing social honour, but a significant change nonetheless confronts women with structural contradictions wherever their reason dictates some decisive action in relation to property or other autonomous conduct in the public world. An excellent early example here - and it is no accident that she is the creation of a woman who had faced enormous personal difficulties in exercising her creative talents - is Frances Burney's Cecilia. Cecilia is wealthy, beautiful, intelligent and refined. She is also in an impossible position. First, her wealth is controlled during her minority by three variously despotic or dangerous male guardians; second, her ultimate access to that wealth is contingent, should she wish to marry, on her husband's agreeing to take her name. Cecilia lacks neither rational faculties, nor intelligence: she is not, in principle, short of money. What she lacks is a world in which she can exercise these faculties with a reasonable degree of dominion. The expectations of society, as well as her own emotional attachments, tell her to marry; but the condition which her father has attached to marriage contradicts one of the founding principles of patriarchal social organization. Cecilia is, simply, blocked by her situation: and though she and her lover do find a sort of escape, it is tremendously to Burney's credit that the novel has something much more subtle than a happy ending.

In an essay on Moll Flanders published in the 1970s, Juliet Mitchell persuasively framed her analysis of Moll in terms of the 'rise of capitalist woman'. The same label would apply readily to another very early heroine; Samuel Richardson's Pamela: a poor servant girl who uses her intelligence, enterprise, cunning (and, it must be admitted, looks) to attain her reward. Resisting the attempts at seduction of her wealthy master Squire Booby, Pamela survives a period of imprisonment and a panoply of forms of physical and psychological coercion, finally persuading him to marry her. But capitalist woman of the genre of Moll and Pamela seems to have been stifled in her infancy - or at least administered a sedative which kept her docile (or, like Becky Sharp, exiled from

88 See King, Crime and Law in England n 13 above 53, 192-19 and 269-274; see also Gatrell, n 37 above, 336-7; Wiener, n 21 above. The legislative abolition of whipping of women did not come until 1817. 
respectability) for a couple of centuries. In Richardson's work, the change came very quickly. If we look at his next novel, Clarissa, we see a different picture. Influenced, perhaps, by Fielding's pungent critique of Pamela as tending to subvert the social order by encouraging servants to seduce their masters in the hope of marriage (and stung, no doubt, by Fielding's merciless, and hilarious, take-off, Shamel $\left.a^{89}\right)$, Richardson's second heroine is decisively punished for her willful moment of self-assertion. Personally favoured and talented - and from a more privileged social background than Pamela - Clarissa resists her family's attempts to marry her to a man she despises, and doubts their distrust of Lovelace, the supposed suitor of her sister. Lovelace rewards Clarissa's trust by abducting, imprisoning and, finally, drugging and raping her. Clarissa finally manages to escape, and then - significantly - as it were punishes herself by refusing to invoke the law to indict Lovelace and by subsiding gradually into death. Between the worlds of Pamela and of Clarissa, the idea emerges that resort to law is in some sense a violation of the norms of feminine sensibility and religious duty. And this in turn results in a privatisation of women's wrongs - in stark contrast to the emerging early modern evidence of women's relatively active use of the legal system through mechanisms such as defamation cases. ${ }^{90}$

Clarissa seems, with hindsight, to have been a turning point. From the mid$18^{\text {th }}$ Century on, what it means to be a female heroine seems to be tied up with self-denial and the containment of self-expression. The odd bright spark appears, even from the pen of Henry Fielding: Sophia Western, the spirited admirer of Tom Jones, defies her father and risks her social position to pursue Tom, for example. But her transgression of male authority is contained firmly within a conventional narrative which leads inexorably to marriage, and indeed to a marriage which turns out to be socially appropriate, even though none of the parties are aware of it at the outset. In Fanny Price we have perhaps the supreme representation of this culture of female sensibility: she spends most of the course of Mansfield Park engaged in a tremendous struggle to contain her feelings, sustain her values and comport herself with dignity in very hostile circumstances. Fanny is often seen as Jane Austen's least interesting heroine: passive, weak, pallid. It is crucial to my argument that this is a very basic misunderstanding. In fact, Austen would have seen Fanny as an image of strength and of individual responsibility - moreover of strength and responsibility in a specifically feminine genre: Fanny's, like Anne Elliot's in Persuasion, ${ }^{91}$ is a moral strength, exercised in private and, often, in silence. Crucially for a rebuttal of the idea that the feminine was unambiguously associated with weakness, the ideal of sensibility was associated with a high degree

89 1741,Penguin Classics 1999.

90 See n 20 above; n 4 above, Chapter 6. Carolyn Conley notes that in Kent, over a century after the publication of Clarissa, the idea of being at once a rape complainant and a respectable woman is an oxymoron: the very fact of bringing her sexuality into the public sphere defines a woman as outside respectability: Conley, n 30 above, 83-85. The observation is interesting in the light of the public reaction to Tess of the d'Urbervilles (see $\mathrm{n} 8$ and 52 above).

91 1818, Penguin Classics 1998. 
not only of emotional sensitivity but also of 'self-mastery'.92 And here, notwithstanding the gendered noun, women were expected to conform perhaps to a greater degree than - though in a different way from - men. Fanny is just as much an agent as Moll Flanders: she is just as rational, and, in her own way, just as strong. But the social terrain on which she is allowed to act has diminished to something approaching Jane Austen's famous 'little piece of ivory'. By the time Fanny silently watches as almost everyone else in the novel behaves badly (and duly gets their just deserts...), the shade of Moll Flanders, the active, transgressive literary heroine of a century before, has paled to the point of invisibility. As George Eliot puts it in the mouth of the embittered Mrs. Transome in Felix Holt, 'What is the use of a woman's will?'; or, even in the words of the more tractable Esther, 'A woman must choose meaner things, because only meaner things are offered to her." 93

Female offenders are not, of course, absent from $19^{\text {th }}$ Century literature. But the assumptions about their conduct and motivations generate some significant and perhaps surprising - insights. We might have expected $19^{\text {th }}$ Century novels to be peopled by offenders like the luckless Nancy in Oliver Twist: ${ }^{94}$ a victim of her circumstances, and unable to extricate herself from the mesmerizing influence of Bill Sikes even when she has reformed. (Indeed, her moral reformation takes place under the influence of Oliver, and hardly seems the product of her own agency. ${ }^{95}$ ) Nancy's story does exemplify - albeit in typically Dickensian monochrome - some of the difficulties of female life in early $19^{\text {th }}$ Century London, evoking the place of prostitution as one of the few avenues open to poor women unable to find a secure footing in respectable society. ${ }^{96}$ Also significant from this point of view is Mary Barton's aunt Esther, in whom Elizabeth Gaskell created a sympathetic yet nonetheless unmistakably moralistic vision of the dangers of female willfulness and loss of reputation. The beautiful and spirited Esther runs off with a man who fails to marry her: having lost her character, she is unable to reinsert herself into either family or respectable community, and sinks into a demoralized haze of alcohol and prostitution. Yet even for these most powerless of early Victorian women, a measure of agency remains, as is eloquently shown by testimony quoted by Judith Walkowitz in her thought-provoking study of prostitution in Victorian society..$^{97}$

But many 19th Century fictional female offenders transmit a far more complex and ambivalent message about women's autonomy. Take, for example,

92 See Rabin, n 18 above, Chapter 4. For Jane Austen's own critique of an excessive sensibility untutored by self-control, see Sense and Sensibility [first published 1811], in which one sister's volatile emotionality is contrasted with another's quiet good sense.

${ }_{93}$ Felix Holt, n 25 above, 374, 407. Interestingly, Esther's comment is a memory of something which she said earlier in the novel, but the two formulations are in fact different, with the first expressed in terms of determination rather than agency: 'She must take meaner things, because only meaner things are within her reach': see vi-vi.

${ }^{94}$ First published $1837-9$.

${ }^{5}$ See L. Rodensky, n 18 above, Introduction and Chapter 1; see in particular 31-2.

96 Mary Barton (1848, Penguin Classics, 1996).

${ }^{97}$ J.R. Walkowitz, Prostitution and Victorian Society: Women, Class and the State (Cambridge: CUP 1980) 13. 
Hetty Sorrell, the respectable farmer's niece loved by George Eliot's Adam Bede. ${ }^{98}$ Vain and cold-hearted, Hetty's beauty attracts the young local Squire, Arthur Donnithorne. After a confrontation with the wounded Adam, Donnithorne withdraws from the scene, to Hetty's distress: but by this time she is pregnant by him. Concealing her situation from her uncle's family, and, Eliot implies, even from herself, Hetty finally leaves her home in search of Donnithorne. Once she is convinced that she cannot find him, she wanders distractedly until giving birth to the baby, who is a short time later found dead under a pile of leaves. In a fascinating portrait of denial, echoing historical data on the frequency of concealment of birth and pregnancy among infanticides, ${ }^{99}$ Hetty asserts her innocence and distances any chance of the exercise of mercy at her trial by her cold and detached demeanour (though she is finally brought to a confession by her cousin, the Methodist Dinah Morris, and is ultimately saved from the scaffold by a reprieve brought by Donnithorne). Hetty is, certainly, in some sense the victim of male irresponsibility. But she is also portrayed by George Eliot as the agent of her own misfortune and as bearing a measure of responsibility for her own fate: her vanity and obtuse misreading of her social situation and power over her lover are held up, unmistakably, to the reader's judgment.

As Lisa Rodensky has argued, the images of criminality across the 19th Century novels are becoming increasingly focused on interior states such as intention or desire: Gwendolen Harleth/Grandcourt, who wishes for the death of her husband in Eliot's Daniel Deronda, ${ }^{100}$ is inclined to feel some responsibility when it ensues, even though it appears that it was the product of an accident. But Gwendolen, like Hetty, though the victim of male selfishness, was previously the author of her own difficulties, having courted the brutal Grandcourt out of the desire to exploit her beauty by marrying into a well-connected and wealthy family. Even Tess, who commits the closest thing to a 'crime of passion', is portrayed across much of Hardy's novel as acting autonomously, albeit in a highly constraining world: she is the victim of male cruelty and of her circumstances, but she is also a willful person, and the reader is left in no doubt of the intentionality with which she commits the murder which condemns her to the gallows. Similarly, her culpability is conceived in terms of concepts central to late Victorian criminal law: her sins before the murder, as Tess herself reflects, were 'not sins of intention, but of inadvertence', ${ }^{101}$ and in one letter to Angel, her reproach is that

98 1859, Penguin Classics, 1980 with introduction by Stephen Gill; cf. Felix Holt, n 25 above - a book which is peppered with references to consciousness, will and intent, and in which the contrast between Felix's good intentions and the evil consequences of his acts are a central theme. His ultimate exoneration - by not only the novelist but the pardoning process - reveals George Eliot's own view of the moral priority of intentions.

${ }^{99}$ See M. Jackson (ed.), Infanticide: bistorical perspectives on child murder and concealment, 1550-2000 (Burlington, Vt: Ashgate, 2002), in particular J. Geyer-Kordesch, 'Infanticide and the erotic plot: a feminist reading of eighteenth century crime' at 93-127.

100 1876, Penguin Classics 1995; Rodensky points out that Eliot also explores in Middlemarch (n 52 above) the idea of purely subjective responsibility in relation to Bulstrode, who compasses, and omits to prevent, the death of Raffles.

101 n 8 above, Chapter 51. 
'You know that I did not intend to wrong you'.102 (It is worth noting that her fate was by this time a very rare one: between 1836 and 1899, only 18 women were hanged for murder of a husband, and five of these executions took place between 1847 and $1852 .{ }^{103}$ By contrast, several hundred men were executed for wifemurder over this period - a figure which represents, as Martin Wiener has argued, significant changes in attitudes to male and female violence over the 19th Century.)

Hetty's and Tess's criminality are entirely different from that of Moll Flanders. Powerful emotions are portrayed as the source of Hetty's and Tess's offences. They act in worlds which are particularly unforgiving of conduct which transgress the boundaries not only of law but of conventional femininity. While infanticide often commanded sympathy from all - male juries, Hetty's lack of confession and apparent lack of remorse condemn her, just as Tess's pride and unwillingness to ask for help seal her fate.104 Yet while both of them lack experience and wisdom, neither Hetty nor Tess lacks rationality or agency: rather, they are prevented by prevailing social norms from exercising that agency in selfdetermining ways.105 Their decisive punishment underlines the state's determination to enforce legal norms and society's condemnation of their violation of the ultimate image of Victorian femininity: care of children and physical docility. It is worth noting in this context that in each of the two cases, the actual or supposed criminal act takes place in the interstices between chapters, outside the reader's line of vision: perhaps symbolizing the unspeakable nature of female violence by the middle of the $19^{\text {th }}$ Century.

But what of Becky Sharp - one of Moll Flanders' very few close literary relatives, and as vivid a portrait of early $19^{\text {th }}$ as Moll is of late $17^{\text {th }}$ Century female agency? Unlike Moll, Becky never reforms - nor is she formally punished (indeed, her actual offences and most egregious breaches of sexual decency, as opposed to breaches of social convention, are hinted at rather than shown - leaving open the interpretation that she is in part a victim of the malicious gossip endemic to the culture of reputation). But she is kept outside respectable society and, eventually, of England: her wit and guile enable her to find financial stability but not the place in the social order which she craves. It is not Becky's agency or resourcefulness which are punished: rather, it is her malice, selfishness and ruthlessness; her amorality and perhaps, above all, in the ultimate early Victorian female sin, her lack of maternal feeling, are what finally exile her from polite society. (It is interesting that, even in the relatively mobile Regency world, Thackeray plausibly portrays Becky's bad reputation as following her across the channel to the continent.)

\footnotetext{
102 ibid, 370.

103 Wiener, n 21 above.

$104 \mathrm{ibid}$, Chapter 4, on the intense focus on the apparent state of mind of female defendants at trial during this period.

105 It might be argued that one of the weaknesses of Tess is the way in which Hardy almost suspends her agency at crucial turning points in the plot. Compared with her otherwise strong and spirited personality - and even in the light of her sense of responsibility or difficult circumstances - her cession at key moments to her parents, to Angel's, and - most disastrously - to Alec's will seem hard to understand.
} 
Whatever the scale of the change, it is generally agreed that by the end of the 19th Century, recorded female crime was at a relatively low level, amounting to little more than $10 \%$ of the more serious offences triable before a jury. Yet these low levels of recorded female crime were juxtaposed with significant late Victorian fears of female criminality, and by a profusion of theories of female dangerousness, often projected onto images of sexually motivated or emotionally rooted crime. ${ }^{106}$ Further, as the activities of female social policy reformers, campaigners for women's education and suffragists began to occupy a larger space in the public consciousness, the fear emerged that female liberation would spell higher female crime. ${ }^{107}$ From the influential late Victorian historian Luke Owen Pike through to 1930s criminologist Otto Pollack and well beyond, the feared association of growing female autonomy with female deviance has continued, apparently impervious to the actual figures of recorded crime, which show no changes in levels of female criminality proportionate to the significant changes in women's social, political, legal and economic position across the $20^{\text {th }}$ Century. Again, this is a persistent myth which finds expression in the world of literary fiction, in which intelligent and active figures like Moll Flanders and Becky Sharp also exemplify female transgression.

\section{CONCLUSION: THE DISEMBEDDING OF 'CHARACTER' AND PERCEPTIONS OF FEMALE CRIMINALITY}

As befits a paper ranging over an unmanageably large terrain, the themes which I am able to draw out in this provisional conclusion are fragmented. Culturally, notions of women's agency, the emergence of psychological individualism, and along with them capacity-based notions of responsibility are emerging even in the early part of the $18^{\text {th }}$ Century. Indeed, they are central to the bourgeois ideals which the genre of the realist novel represents. But this does not entail that they were the primary driving forces in the criminal process in which - as in the political process - bourgeois interests took over a century to prevail. As in the older, celebrated case of the attribution of criminal responsibility to animals ${ }^{108}-\mathrm{a}$ practice which persisted in several parts of Europe right up to the start of the modern period - criminal justice arrangements can - and sometimes need to draw on patterns of responsibility-attribution which are strikingly different from those predominating in contemporary moral thinking or polite culture. In $18^{\text {th }}$ Century England, practices of criminal responsibility-attribution were still largely

\footnotetext{
106 See n 78 above, 68ff; n 97 above; and, in relation to similar concerns about female criminal pathologies in France, R. Harris, Murders and Madness: Medicine, Law and Society in the Fin de Siècle (Oxford: Clarendon Press 1989).

${ }^{107}$ L.O. Pike, $A$ History of Crime in England vol 1 (London: Smith, Elder \& Co., 1873) 527-9.

108 E.P. Evans, The Criminal Prosecution and Capital Punishment of Animals (1906, London: Faber and Faber, 1987).
} 
operating in terms of information and assumptions about conduct, character and reputation - assumptions which are illuminated by the novels we have considered, and which the particular resources of, and demands upon, the criminal process enabled and dictated. Defective female moral character could underpin the criminalization of women just as it did that of men; but women's relatively secure position in the agricultural economy of early modern England, along with the vitality of informal social controls in rural areas, kept them a minority of offenders officially proceeded against.

The exception - and the factor which I would argue comes closest to explaining the various records of relatively high levels of female criminality - had to do with urbanization. This was already a significant phenomenon by the end of the $17^{\text {th }}$ Century, and it posed a challenge to the informal mechanisms of social control which were such an important supplement to formal criminal justice in 18 ${ }^{\text {th }}$ Century England. ${ }^{109}$ This was particularly so for women, for a number of reasons. From the late $17^{\text {th }}$ Century, England saw very significant population flows of women from countryside to urban areas, with cities exhibiting an overrepresentation of female inhabitants right through to the end of the $19^{\text {th }}$ Century. This gender imbalance was, of course, particularly acute during war-time - another factor which helps to explain the very high levels of recorded female crime in London in the last decades of the $17^{\text {th }}$ and first of the $18^{\text {th }}$ Century. ${ }^{110}$ Many of these women were single, and they occupied particularly economically vulnerable positions in the unstable early capitalist economy. ${ }^{111}$ The difficulty of finding safe and affordable accommodation which was consistent with prevailing norms of female respectability was a particular, and growing, problem for women in terms of presenting evidence of good character. For the distinction between lodging houses and houses of 'ill repute' was notoriously blurred - and lodging houses were the only resort for those not in domestic service or otherwise provided with accommodation by their employers. ${ }^{112}$

As John Beattie has shown, these significant numbers of women like Moll often independent of men or family structures, hence escaping patriarchal control, and unstably articulated with the economy - became from quite early on a specific object of respectable fears. ${ }^{113}$ At the end of the $17^{\text {th }}$ and start of the $18^{\text {th }}$ Century, Beattie has calculated - extrapolating from figures for 1694 and 1704 - that $80 \%$ of the women tried at the Old Bailey for theft were unmarried. It was anxiety about the danger which these independent and economically insecure women represented which seems likely to have prompted, in 1691, the extension of benefit of clergy to women. This would have removed a significant factor inhibiting the prosecution of women, who were formerly liable to capital

\footnotetext{
${ }^{109}$ See Morgan and Rushton, n 24 above, Chapter 2.

${ }^{110}$ See King, Crime and Law in England $\mathrm{n} 13$ above 212-213; Beattie, $\mathrm{n} 26$ above, 69-71.

111 See G. Stedman Jones, Outcast London: A study in the relationship between classes in Victorian Society (1971

[Oxford University Press], Penguin, 2nd ed. ,1984) 20-38 and 83-88; Beattie, n 26 above; King, Crime and Law in England, n 13 above, note 25.

112 See $\mathrm{n} 78$ above 64ff; Feeley and Little, n 22 above.

113 See Beattie, n 26 above, 64-71.
} 
punishment for even trivial offences. A little, later, specific anxieties about forms of property crime particularly associated with women were, conversely, removed from benefit of clergy (shoplifting in 1699 and thefts by servants in 1713).

More general fears about the potentially corrupting effects of urbanization and commercialization, vividly reflected in the novels, were gradually leading to the development of a set of ideas about a compensating code of polite manners a conventional public morality which would incorporate the newly emerging middle class. As we have seen, one aspect of this was the culture of sensibility - a culture in which women became in an important sense primary bearers of the marks of civilization, both in themselves and as those responsible for the propagation of this culture in their roles as the socialisers of children. It is easy to imagine that this emerging, feminised, culture must have exacerbated the problems of independent urban single women like Moll: without, as she repeatedly puts it, 'friends' in polite society, it would have been almost impossible for urban women to find a secure social and economic footing - circumstances which must have increased the temptation to opt, like Moll, for a life of crime. Equally, the perception of uncontrolled and dangerous women as a significant social problem would have increased the willingness to prosecute and punish. Notwithstanding arguments about continuing 'leniency' to women across the $18^{\text {th }}$ Century, ${ }^{114}$ Walker's differentiated analysis of the treatment of different forms of crime in $17^{\text {th }}$ Century Cheshire ${ }^{115}$ suggests that it would be worth engaging in a similar analysis of female property crime specifically in urban areas. Only on the basis of this kind of research will be in a position to assess whether the fears about female criminality which surface so clearly in the spectacular Old Bailey figures for 16841720 may in fact have persisted, in relation to specific types of urban crime, for a yet longer period.

Throughout the period from Moll to Tess, literary sources show clearly that women are fully recognized as human, and increasingly as psychological, agents. Yet they are also recognized as operating within a very specific set of constraints constraints which are shifting over time. The real problem for women, it seems, is not so much assumed weakness or lack of rational agency, but rather the constraints and expectations associated with femininity in general and with marriage and motherhood in particular. In this respect, it is significant that all of the women literary figures we have considered are, in effect, childless, and that many of them are unmarried or, as we might say of Moll and Becky, somewhat loosely attached to the roles of both wife and mother. Here again, there is a historical shift: Moll, who has a remarkable capacity for losing track of her children, without apparent distress, is judged far less harshly than Becky, Hetty or even the understandably ambivalent mother, Tess. Women's role as the cultural bearers of developing markers of polite manners - along with the status involved in a man's economic ability to support a wife at home, in charge of the domestic

114 See King, Crime and Law in England $\mathrm{n} 13$ above, Chapter 5.

115 n 4 above, Chapter 5. 
sphere - fed into a longer-standing image of women as less dangerous than men. But when women's social position took them outside these emerging conventions - because of their poverty or sexual adventurousness, or their presence in urban areas in economically fragile and independent positions - the increasingly organized state quickly became interested in controlling them.

From the early to the late $19^{\text {th }}$ Century, as Zedner has shown, there was certainly a move from treating women as criminally responsible to constructing them as the objects of various new social regulations framed in terms of moralized conceptions of health and public order dressed up in scientific garb: the control of inebriates and prostitution were prominent among these. But up to this point, there is little reason to suppose that the images of agency (equally if not more strongly associated with characters of lower status like Moll and Pamela) which are so central to the novels are any less present in the court room. The literary transition from Moll to Tess does, therefore, represent something real: but it is a reality about women's social environment rather than an emerging inability to conceive women as moral agents.

In the slow movement from a world in which criminal judgment is motivated by type- or status-based assessments of culpability, to a world in which individual psychological states become the object of proof in criminal trials - a move which is not, in my view, complete until the mid-20th Century, and which encompasses even today only part of the terrain of criminal law - Moll Flanders stands as a fascinating landmark. The question which she poses - what counts as good character, as being a gentlewoman, in an emerging capitalist world in which the same characteristics are needed for sharp practice and for commercial success echoes down the centuries since her creation, and has as yet not been satisfactorily answered. In the long search for an answer, Moll's female descendants were caught up for over two centuries in a clutch of normative developments - of manners, morals and, finally, medicine - which contributed to the unthinkability of Moll by the era of Tess. In the mean time, the criminal process was being slowly reshaped so as to project the central attribution of responsibility onto factual, psychological states which - once the appropriate institutions had been developed - could be operationalised irrespective of dissent about criteria of evil, wicked conduct or bad character. In the gradual dismantling of a status society, the status of womanhood appears to have been reinforced before becoming incompletely - one of the last fixed marks of social status to be dissolved. I leave it to my audience to judge whether, in 2007, Moll Flanders is thinkable again - and, if so, whether this is a good thing or a bad. 